\title{
How much green in the greenhouse?
}

\section{Washington}

WHEN there is doubt, speak out. Or hire some researcher to do it for you. Uncertainty over how greenhouse warming will affect the climate — and the public's craving for answers - is providing a lucrative market for a few outspoken proponents and sceptics who are willing to go beyond the usual caveats and caution of science into outright advocacy.

It will be many years before science can truly understand the relationship between rising levels of carbon dioxide and other greenhouse gases and global climate. But that is not stopping the public calls for limits or curbs on present-day emissions. With such potentially costly policies on the line, both industry and the environmental groups seem to be convinced that money spent on a few well-spoken researchers goes a lot further in winning over the public than does money for research itself.

These researcher/advocates have become so visible, in fact, that rumours abound of the big money that can be made by jumping aboard the lecture circuit. One version paints industry as so eager to discount the existence of global warming that it is dangling research grants and fat fees in front of any scientist willing to be a public sceptic. Another version accuses the environmental movement of sparing no expense in its quest to convince the public that global warming is already here, and certain to grow worse unless dramatic steps are taken to curb the world's production of greenhouse gases.

Last month, for example, a newsletter produced by researchers at the University of East Anglia Climate Research Unit in Britain, Tiempo, put the potential profits of public scepticism at $\$ 10,000$ a month for researchers who live in the United States and "have friends, or make them, in the fossil fuel industry." In turn, sceptics say that industry pales next to the environmental groups - the "biggest lobby in America" - when it comes to sponsoring friendly researchers.

The truth is that scientists on either side of the debate are collecting sizeable fees for offering their versions of the truth. Contrary to the rumours, however, no one appears to be getting rich. Interviews with several of the scientists who travel the lecture circuit found that none earned more than $\$ 30,000$ last year.

Greenhouse sceptic Patrick Michaels, a climate researcher at the University of Virginia, made 43 speeches last year and earned $\$ 25,490$. Another sceptic, Robert
Balling of Arizona State University, made about 15 speeches for which he says he was paid slightly more than $\$ 10,000$.

On the 'believer' side, Stephen Schneider, a climatologist at the National Center for Atmospheric Research at Boulder, Colorado, made about a dozen paid speeches last year and earned about $\$ 30,000$. And Michael Oppenheimer, a staff researcher at the Environmental Defense Fund, made about 50 paid and unpaid speeches last year. He says he has "netted less than $\$ 15,000$ " from speeches given during the past three years.

Other rewards for advocacy go beyond lecture fees. The Pacific Research Institute for Public Policy and the Cato Insti- sceptics show up more in the press than they do in the scientific community. Although about 70 per cent of researchers (members of the American Meteorological Society and the American Geophysical Union who were sampled by Gallup pollsters) thought that global warming was under way, according to a survey by the centre, only about half of the scientists quoted in newspapers such as the Washington Post and the Wall Street Journal held that view. PR, in short, works.

"I think industry is making a concerted effort to confuse the public on this issue," says Daniel Lashoff of the Natural Resources Defense Council. "They're sowing the seeds of confusion by paying hired tute, two think-tanks that defend the free market, are publishing books by Ballings and Michaels. And Michaels' resume lists a one-year $\$ 50,000$ grant from an anonymous source - someone, presumably, who approved of his sceptical line.

Whatever the motives of their sponsors, most of these researchers describe their constant touring and advocacy as primarily a labour of love (or duty). The work, they say, pays just a fraction of what a scientist can earn as consultant for the pharmaceutical industry or by providing expert testimony in court.

Although all the researchers interviewed emphasize that they charge nothing beyond expenses for many - sometimes even the majority - of the speeches they make, the fees add up to quite a tidy sum. The best-known greenhouse speakers such as Schneider and Michaels can make $\$ 3,000$ or more per lecture. "I don't think the [sceptics] are in it for the money any more than I am," says Schneider. "But if the money's there, we'll take it."

Who is winning this war of words? The Washington-based Center for Science, Technology and Media has found that the guns to take pot shots at the science and scientists, rather than arguing policy."

Researchers who partake in the "travelling dog-and-pony shows" - the seemingly endless series of lectures, debates and panel discussions before such nonscientific groups as the United Ski Industries Association and the Council of Industrial Boiler Owners - defend it as a necessary evil brought on by environmental politics. Decisions are being made now, even without scientific consensus, they say. Better that people be exposed to a little one-sided science than none at all.

By paying outspoken researchers to spread the word with a scientific seal of approval, Schneider says, both industry and environmental groups are simply ensuring that their side will be heard: "I don't think the money is making these guys say what they do; they were saying the same thing before the money came along. All it's done is leverage the probability that they will get in the paper."

Sometimes, Schneider says, researchers must become advocates. And if it means making some money on the side, so be it.

Christopher Anderson 